\title{
Ceramics, Ethnohistory, and Ethnography: Locating Meaning in Southern African Iron Age Ceramic Assemblages
}

\author{
Innocent Pikirayi* • Anders Lindahl
}

\begin{abstract}
For ceramics to be relevant in the Southern African Iron Age, archaeologists must broaden their theoretical base to include social and other contexts when interpreting material culture items such as pottery. Pottery remains critical in understanding cultural dynamics in the region for the past two millennia, but current usage is narrow in scope. Using ethnohistorical data and archaeological examples from South Africa and Zimbabwe, we argue that pottery provides valuable information on the region's Iron Age, if archaeologists address the social meaning of ceramic assemblages. Ceramic production among rural communities provides the basis on which a wide range of social issues are discussed and used to critique pottery recovered from archaeology. Ethnography suggests that ceramic assemblages are context specific, and archaeologists are cautioned against making generic statements on the basis of similarities of vessel shape and decoration motif.
\end{abstract}

Résumé Pour faire en sorte que la céramique contribue aux études de l'Âge du Fer en Afrique australe, l'interprétation archéologique doit prendre meileure mesure des différents contextes dans lesquels évolue la poterie. La poterie joue un rôle critique dans la compréhension des dynamiques culturelles de la région au cours des deux derniers millénaires, mais elle demeure limitée dans son usage. Sur la base de données ethnohistoriques et d'exemples archéologiques tirés d'Afrique du Sud et du Zimbabwe, nous soutenons que la poterie peut fournir des informations précieuses sur l'Âge de Fer régional si les archéologues s'attachent à examiner la signification sociale des assemblages céramiques. La production potière dans les communautés rurales nous permet de traiter un large éventail de questions sociales et de formuler une critique de la poterie issue de

\footnotetext{
I. Pikirayi $\left(^{*}\right)$

Department of Anthropology and Archaeology, University of Pretoria, Pretoria 0038, South Africa e-mail: innocent.pikirayi@up.ac.za
}

A. Lindahl

Laboratory for Ceramic Research, Department of Geology, Lund University, Lund, Sweden e-mail: Anders.Lindahl@geol.lu.se 
l'archéologie. Nos données ethnographiques suggèrent que les assemblages céramiques doivent être traités dans leur contexte propre, et mettent les archéologues en garde contre les explications générales sur la base de similarités morphologiques et décoratives.

Keywords Ethnohistory · Ethnography · Ceramic assemblage · Social meaning · Production · Distribution

\section{Introduction}

Many studies of contemporary pottery production have helped inform the archaeological record. Groundbreaking work by Arnold (1988, 1991), David and Kramer (2001), David et al. (1988), Deal (1988, 1998), Rice (1987), Rye and Evans (1976), and Shepard (1980), among others, have demonstrated the value of technology and ethnoarchaeological research in understanding ceramics recovered from archaeology. For a long time within the African continent, ceramic studies have focused mainly on typology, either due to the expense of laboratory procedures involved in conducting technological investigations or the failure to pose relevant social questions on existing archaeological assemblages. In the past decade, researchers in sub-Saharan Africa have increasingly embraced ethnoarchaeological studies, a greater number using a chaîne opératoire approach to address sociological aspects of ceramics (see, e.g., Fowler 2008; Fredriksen 2007; Gelbert 2001; Gosselain 2001).

Although ceramics generally constitute the largest artifact category in Southern African Iron Age studies, archaeologists are increasingly wary of their parochial usage, mainly restricted to addressing questions of relative chronology, identifying prehistoric human group identities, and tracing movements of people from one region to another (e.g., Huffman 1989). Archaeologists are aware of the need to address the usage and sociological context of pottery in the past, but often fall short of posing relevant questions to their data (Pikirayi 2007). It is our view here that some of the questions archaeologists must focus on are found in the region's rich ethnohistoric and ethnographic record as well as the technology of ceramic production processes (Lindahl and Pikirayi 2010). Further, we are aware of the limitations that current Iron Age studies pose in the relationship between pottery and past populations as represented by these artifacts. We show in this paper that the value of ethnographic and ethnohistorical studies in pottery rests not only in illustrating functional aspects of ceramics but also highlighting a wide range of social aspects including exchange, ritual, and ceremony. Using other associated material remains recovered at archaeological sites, we show that it is possible to identify or predict ceramic patterning associated within household contexts (see, e.g., Deal 2005). Very often archaeologists underestimate the value of ethnoarchaeological studies in predicting and identifying prehistoric ceramic patterns found at some archaeological sites. We attempt in this paper, using ethnohistorical studies and observations of ceramic production among rural communities in northern South Africa and Zimbabwe (Fig. 1), to understand the social meaning of ceramic assemblages. Our observations suggest that such meanings are site or context specific, regardless of whether resemblances and patterns exist as inferred by shape and decoration. We use a number of archaeological examples dating to the last five centuries, a period also coinciding with documented oral and written historical accounts. 


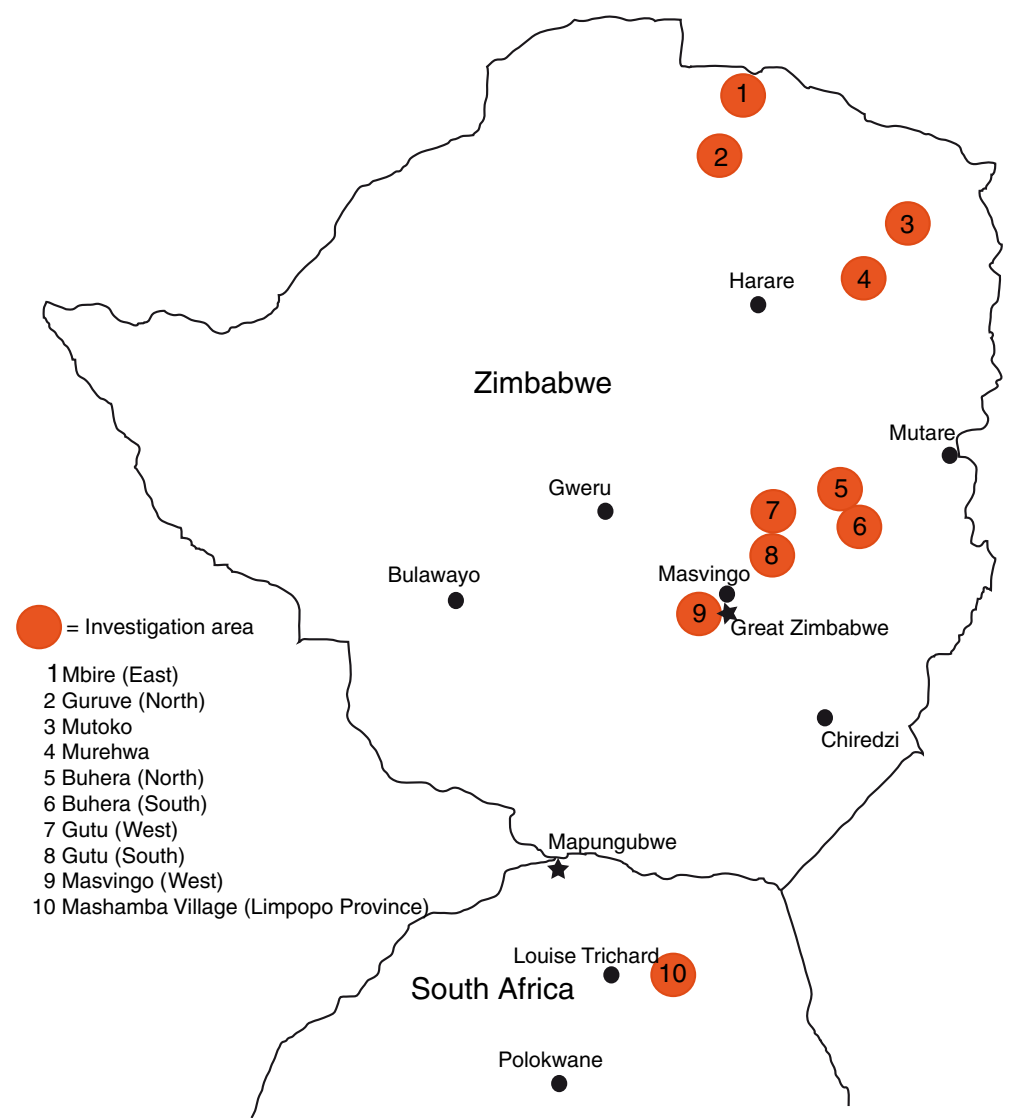

Fig. 1 The research area: the eastern half of the Zimbabwe plateau and northern South Africa

\section{The Southern African Iron Age, Ethnohistory, and Ethnography}

Our conceptualization of this project arises from the growing dissatisfaction with the manner in which Southern African archaeology has interpreted and portrayed past societies. Some of the criticism (e.g., Vansina 1995) has been leveled at the way archaeologists use ceramics, particularly style (e.g., Huffman 1980, 1989) to define culture units and explain change over the last two millennia. This dissatisfaction is impelled by the absence of discussion about social issues affecting and driving past societies, and growing skepticism that ceramics alone are not able to address this. While archaeologists may argue that they are in fact using pottery to address the relationships between culture and language, use of space, and origins of modern ethnic groups (see, e.g., Calabrese 2000, 2005; Huffman 1989, 2002, 2007; Huffman and Herbert 1994/1995) and may cite social organizational aspects (see, e.g., Huffman 1996, 2007, on the Central Cattle Pattern), these approaches are effectively grounded in conventional typologies (see critique by Hall 1983).

Recent research in Southern Africa has shown the value of ceramics in understanding broader regional and social contexts of sociopolitical alliances, which also involve marriage and the movement of women from one group to another (Esterhuysen 2008). 
These studies serve to enhance understanding of the meaning of ceramic assemblages, since pottery is a dynamic rather than static artifact in a given cultural context. Such approaches also support our understanding of recent ethnohistories and the ethnography associated with the communities we are studying. More important, when studying Iron Age ceramics in Southern Africa, there is need to develop research approaches whose objective is to understand meanings beyond conventional typologies.

In this paper, we examine ceramics manufactured and used during the last five centuries: a period characterized by complex social, economic, and political interactions among societies. Such interactions also involved different degrees and intensities of encounter between Africans and Europeans in Southern Africa, a development which may have impacted local forms of material culture including ceramics. Our focus is on ceramics and associated contexts dating to the protohistorical and historical periods, where some societies' material signatures are also captured in written and oral sources. These sources provide the context in which social aspects of archaeological material may be framed and understood. We do not claim that all of the ethnographic observations made during this period can help inform ceramic production and spatial patterns of earlier, prehistoric periods. Nor do we agree with Iron Age archaeologists who assume that certain social institutions and practices found in many ethnographically documented societies in the region are primordial (see Huffman 1996, 2007 and critique by Lane 1994/1995). Rather, we regard and we are in favor of those data collection methods in ethnography designed to capture the specific, rather than generic, social meanings and ordinary activities of the societies we are studying. In this paper, we present three archaeological case studies from three successive centuries. We follow the approach of "tacking" between the ethnographic source and the archaeological subject, advocated by Alison Wylie (1985) and Ann Stahl (1993), which situates ethnoarchaeological observations in an historic context of continuity and change. Tacking involves comparing similarities and differences in material evidence observed in the present, with the evidence found in the ethnographic and historic past as well as in the archaeological record. This builds up a dynamic picture of material culture practices within their historic contexts (Stahl et al. 2008) and helps eliminate potential bias due to reflexivity.

\section{Research Aims and Objectives}

In archaeology, we often interpret archaeological assemblages as cultural material from a single horizon or layer, and an archaeological site primarily as a locus of culturally interpretable material. Ceramics in this case become valuable tools for dating and defining stylistic patterns and change, which have also been used to define human group identities (Pikirayi 2007). This approach fails to address material culture production, distribution, and social networks of interaction. This paper aims to address this knowledge gap in Southern African Iron Age archaeology by investigating the social contexts in which ceramics are produced and used. Specifically, by examining present-day production and also distribution of pottery in rural households, and by exploring possibilities of using available archaeological data to account for on-site and regional dynamics during the archaeological past, the paper seeks to understand the meaning of archaeological ceramic assemblages. The objective is to understand ordinary aspects of daily life through ceramics, since human behavior within the domestic space is also socialized (Bourdieu 1977). 


\section{Conceptual Frame and Methodology}

Current trends in African archaeology show increasing usage of ethnographic and ethnohistorical approaches in interpreting ceramics (see, e.g., Ashley 2010). Contemporary pottery manufacture is also taken into account to understand social aspects of the past. In 2008, a symposium in Dakar brought together archaeologists and ethnographers to establish common terminology and the necessity of understanding impressed or fiber roulette pottery in West Africa. The six papers published in Azania (see Haour et al. 2010; Haour and Manning 2011) confront archaeological and ethnographic data to understand the role of ceramics in mediating and tracking social interaction and cultural change. All the papers make use of data from present-day pottery manufacturing techniques and apprenticeship networks to understand the archaeological past. Gosselain (2011) revisits the question of why potters decorate their vessels (see David et al. 1988; Haour et al. 2010) and attempts to demonstrate aspects of social organization, and scale of social interaction, represented in the choice and adoption of different decorative types. Some archaeologists employ the chaîne opératoire approach (Fowler 2008), which assumes that potters' choices at every stage of pottery making are guided by social factors that potters learn as members of social networks or groups. These choices include selection and preparation of raw materials, observance of ritual and beliefs regarding clay and temper, fabrication practices, decorative techniques, firing, storage, and distribution among others. The choices also provide a technical style for a pottery-producing community which allows ethnoarchaeological work with one group to be compared systematically with that of other groups in ethnographic and ethnohistoric settings and over time. It is also possible with the chaine opératoire approach to compare technical styles to address local innovations and adoptions of practices within and between groups and even across crafts. This provides a more solid basis for interrogating past uses and interpretation of ceramic style (Huffman 1980, 1989), and this paper may be regarded as some form of gendered chaîne opératoire (see, e.g., Lyons 2009). Gosselain (2011) problematizes the approach on the basis of ethnographic observations, and places decoration once again in the spotlight, examining it from a broader perspective.

Through aspects of stylistic experimentation and group identity, ceramics can demonstrate microscale processes in the archaeological record. By focusing on major regional developments such as cereal agriculture and craft specialization that are mirrored in the ceramic traditions of the Lower Tilemsi Valley of Mali, Manning (2011) argued that stylistic experimentation went hand in hand with the major socioeconomic changes characterizing the region. Guèye (2011) has, through ceramic manufacture, attempted to address the issue of social relevance and ethnic identity. Studying the Halpulaar populations of the Middle Senegal Valley, he argues that decorative attributes of the ceramics from this region inform not only the social identity of their makers but also the identity of their users. He observes that ceramic decoration is structured into simple and complex schemes, which in turn reproduce the social hierarchy of Halpulaar populations. It is within this broader objective of trying to understand the social value of ceramics that we propose here a methodology that accepts the communicative value of ceramic assemblages in society (Fisher 1984; Pikirayi 2007). This is premised on the fact that pottery is not a static but a mobile artifact which expresses a wide spectrum of social activity. 
In order to document the social context of archaeological ceramics, we employed approaches grounded in ethnoarchaeology and ethnographic research. A desktop assessment of available ethnographic literature and related ethnological studies was conducted to evaluate the degree to which early European and other observers provided information on pottery production and the social context in which pottery has been used among various societies in Southern Africa during the last five centuries. These sources include George McCall Theal's Records of South Eastern Africa (1898-1903), studies commissioned by colonial governments such as Schofield $(1943,1948)$ and Van Warmelo (1944), and reports published by the Rhodesian Native Affairs Department Annual. Detailed studies by Lawton (1967) on pottery production processes among various ethnic groups in the Southern African region were also used. In addition to written sources, we also used ethnoarchaeological data collected in northern South Africa (Fig. 2). Here, potters manufacture vessels for domestic and commercial purposes, and their craft has wide regional distribution. To broaden our scope, we also included ethnoarchaeological data collected in 1988-1991 and 1998-1999 from observations of pottery manufacture in northern and eastern Zimbabwe (Lindahl 1995, 2000, 2003; Lindahl and Matenga 1995; Lindahl et al. 2000) (Fig. 3); in total, we interviewed 53 potters. Such observations documented a wide range of subjects involved in ceramic production. This included how the knowledge was learned and transmitted from one person to another; the meaning behind the decoration of pots; rituals and taboos involved in the collection and preparation of clays; and the shaping of vessels and firing of completed products. The objective was to understand the ideas behind a ceramic assemblage in the modern context and its archaeological relevance, if any.

\section{Data Presentation}

We first discuss the archaeology connected with the protohistorical and historical periods of northern Zimbabwe, which span some five centuries. Finding contexts are reviewed in terms of where we believe the various ceramic assemblages recovered by

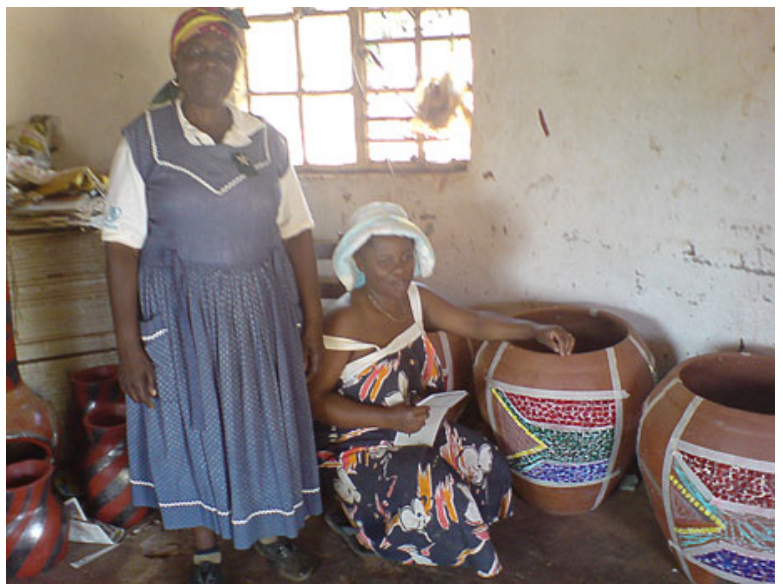

Fig. 2 Potters from Mashamba village, northern South Africa, displaying their wares. Note the decoration motifs depicting the South African flag. Photo by A. Lindahl 
Fig. 3 A group of potters processing clay for pottery manufacture, Guruve area, northern Zimbabwe. Photo by A. Lindahl

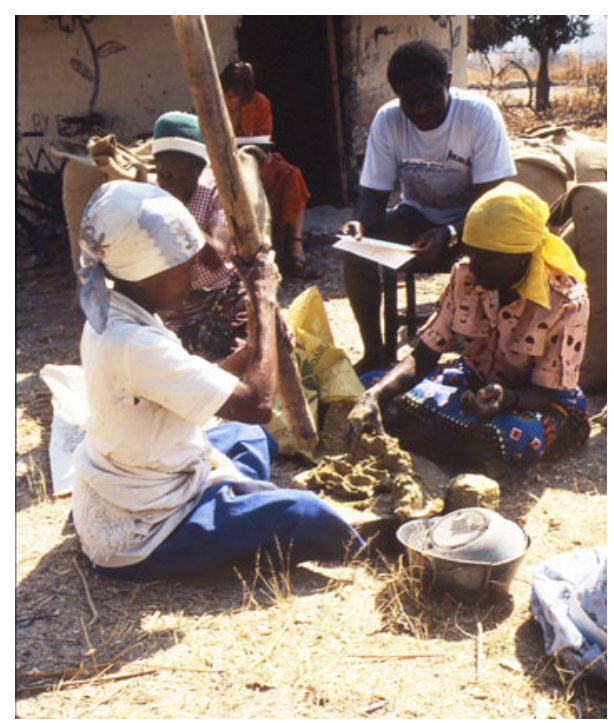

archaeologists suggest that pottery was socialized in the past. This also includes references to or inferences involving ritual activity. This is followed by the presentation of ethnohistoric and ethnographic records mentioning pottery and the various contexts in which it was used by some groups in northern South Africa and southern Zimbabwe. Finally, we present the findings of our own observations among potters in manufacturing and distributing of their craft. The objective behind assembling these three types of data sets was to help inform archaeological data in terms of contextual meanings accorded to ceramic assemblages.

\section{Archaeology}

Although the Portuguese recorded their experiences in southeastern Africa from the beginning of the sixteenth century onwards, their observations are conspicuously devoid of ethnological data on domestic industries such as pottery manufacture and use. This is most surprising given that the Portuguese took control of trade that brought in large quantities of imported ceramics and other items such as glass beads and glassware from Asia and Europe (Pikirayi 1993). However, their trade with the Mutapa state in northern Zimbabwe is associated with the development of local ceramic traditions recovered at a number of places. This paper reassesses ceramic assemblages associated with the Musengezi Iron Age tradition, still in existence in northern Zimbabwe by the fifteenth or sixteenth century, as well as that from Mutapa state capitals found in the region and dating from the fifteenth century, and Baranda field identified with the seventeenth-century trading settlement of Massapa (Pikirayi 2009).

\section{Ceramics from Burial Contexts}

The Musengezi tradition is defined by wrapped-fiber or bead-impressed pottery found in both burials and settlements in northern Zimbabwe (Pikirayi 1987). The biggest site 
of the tradition recorded to date is Mbagazewa (twelfth to fifteenth centuries), which served as a major burial site. Here, archaeological excavations revealed human skeletal remains of at least 70 individuals in two stratigraphic layers (Crawford 1967). These skeletal remains had their ornaments wrapped in shrouds of matting or bark cloth and appear to have been placed in a sitting position, surrounded by pots. About a hundred complete pots, decorated with horizontal bands and panels of comb-stamping, wrapped fiber, wire, or bead impressions were recovered, associated with the human remains. The site has been interpreted as a burial place for chiefs or some important persons of the same lineage (Huffman 1996; Pwiti 1996). Similar pottery has been recovered in domestic contexts at various sites in northern Zimbabwe, suggesting that, within that tradition, no special vessels were made to accompany the dead to their final resting places, but rather, the same pots provided spiritual continuity between the living and the dead. To understand the social context of ceramic assemblages from Musengezi tradition burials, one needs to provide a multiple contextual frame with these artifacts perceived as representing a range of human actions, reflecting social connections between the living the ancestral world (see, e.g., Marufu 2008; Pwiti and Mahachi 1991).

\section{Ceramics from Elite Centers}

The sites described here as elite centers are located on the summit of Zvongombe Hill, immediately south of the Zambezi Escarpment region of northern Zimbabwe. Such sites are identified with the Zimbabwe tradition, characterized primarily by wellcoursed stonewalled enclosures. The appearance of this tradition in northern Zimbabwe since the middle of the fifteenth century coincides with the rise and development of the Mutapa Kingdom or state in the area (Beach 1980). Zvongombe Hill has two stonebuilt enclosures. The site to the south, referred to as Zvongombe South, was built on a skewed rectangular plan, enclosing a number of circular houses plastered with clay (Pwiti 1996). Recovered from house A-the most complex circular structure $8.5 \mathrm{~m}$ in diameter, with a cross wall —were four large ceramic vessels, 70-75 cm in diameter, sitting on either a plastered surface or natural earth cut through these surfaces. Two of the pots contained ash, cattle bone, and potsherds. Other associated finds included spindle whorls, round pebbles, and a gold bead.

The vessels from Zvongombe South reflect, in part, a domestic context associated with food consumption and also storage of high-value items and goods designed for ritual activity. The interpretation of this site as a royal kitchen as proposed by Huffman (1996) - based on seventeenth century accounts by Portuguese chronicler Antonio Bocarro (Theal 1898-1903: 357) — is inconsistent with the archaeological evidence that suggests social activities beyond food consumption. House A must have served storage functions as suggested by the massive vessel sizes. These vessels were too large to transport and practically inconvenient in serving solid foods. Among the Venda speakers in northern South Africa, royalty often kept some vessels away from public view for purposes of ancestral worship, but the same vessels would serve as drinking vessels for the chief and his closest associates (van Warmelo 1944). Without prescribing this interpretation to the vessels from Zvongombe, we caution against the use of ethnographic evidence based on ill-defined criteria to identify site activity areas. 


\section{Ceramics from Trading Settlements}

To the northeast of Mt. Fura, across the auriferous Mukaradzi River in the middle MazoweRuya basin, is the archaeological site of Baranda, part of a wider settlement complex some $5 \mathrm{~km}$ in radius. The settlement complex, which is largely defined by ceramic scatters, dates from the sixteenth century and contains both local and imported Asian and European ceramics, glass beads, and glassware traded into that area until the late seventeenth or early eighteenth centuries. According to the descriptions in Portuguese written sources, the location of Baranda coincides with the trading site of Massapa. Local material, especially graphite-burnished pottery, shows continuation of the Zimbabwe tradition into the historical period. Archaeological investigations attest to the nature of interaction between external traders and local people under the control of the Mutapa Kingdom (Pikirayi 1993, 2009).

Although Massapa is presented in written sources as an essentially Portuguese trading settlement, the archaeological evidence suggests the presence of a very large African population living there. The local graphite-burnished ceramics found there show the social context in which the inhabitants operated in the conduct of trade, which also involved gold mining in the adjacent Mukaradzi valley. The presence of burnishing tools suggests that this pottery was manufactured there. Soot on some of the sherds attests to some cooking activities, again in support of the commercial undertakings there. Although Portuguese written accounts do not mention this pottery in their discussion of trading activities in northern Zimbabwe at the time, the archaeological evidence clearly attests to this artifact category as the most dominant at some of these sites, providing the social context in which commercial activities took place.

\section{Ethnohistory and Ethnography}

Given the limitations of Portuguese written sources indicated previously, we focused on nineteenth- and twentieth-centuries' European observations on hinterland African societies. Some of these observations provided information on local material culture items in terms of their production, ordinary as well as specific ritual usage, and the broader social context in which they were situated.

Theodore Bent (1893 [1969]) noticed pots among Karanga and other households in "Mashonaland" on the Zimbabwe plateau. His references to pottery manufacture, though limited, are quite useful (see pp. 45-46). For the Chivi district to the southwest of Great Zimbabwe - a site which he excavated - he mentions villages that had a monopoly on pot making and which traded pottery for grain and iron tools, pointing out that such villages practiced no agriculture and did not keep cattle. He also made an illustration of the interior of a Karanga hut, where he shows some 15 clay pots in association with grinding stones and basketry, with some in use for food preparation (Bent 1969: 274).

More detailed research on pottery manufacture and use comes from the works of ethnologists commissioned by colonial governments in Southern Africa during the first half of the twentieth century. Here, we summarize their observations. All mention clay pots as part of household material culture items of all farming societies in Southern Africa (see especially Lawton 1967). These are not the only clay objects or features found within the household (Berlyn 1968), as for example the Shona hut is built of pole and clay plaster and its floor is made of "beaten" clay. Features within such structures may include some skirting or some kind of ledges, platforms, or kerbs also made of 
clay (Taylor 1927). The pots come in various shapes and sizes and serve different functions, some involving ritual and ceremony. Although pots are normally regarded as cooking, storage, and serving utensils (e.g., Stead 1947: 102), they are also part of many local burial practices, with some people being buried accompanied by pots or placed inside pots. The association of pots with the grain bin and other basketry signifies their strong connection with grain and other crop production among indigenous societies in Southern Africa. The pots are also an important component of rain making and have been found in associated sites either as functional objects or offerings to the ancestral world. Among some groups, certain vessel types are used in puberty rites and rituals (Stead 1947: 100). Some vessels serve functions related to ancestral worship, as is the case of multi-mouthed pots recorded among the Venda of the Zoutpansberg region of South Africa (Lawton 1967; van Warmelo 1944).

\section{Contemporary Pottery Production}

The studies carried out on contemporary potters provided a broader comparative picture. On one hand, potters made their products essentially for domestic use, including limited exchange within neighboring villagers, or on the other hand, produced wares in large quantities for sale within the region or beyond. This has implications on the size of the production assemblage and its social meaning.

Located some $45 \mathrm{~km}$ east of Makadho, in the Limpopo Province of South Africa, several villages are involved in pottery production. Geographically, this area is southern Venda (see Stayt 1931), situated south of the Zoutpansberg mountains. The village of Mashamba is perhaps the most well known, in terms of the quality and wide range of wares they produce for domestic use, for within the region, and beyond. The bulk of production consists of cooking and storage vessels, but there is also manufacturing of vessels for purposes of interior and exterior décor (Fig. 4). The 21 potters living there are all women in their forties or older in terms of age. They all speak Venda although some of them have married into the local population from neighboring Tsonga-speaking and Sotho-speaking groups.

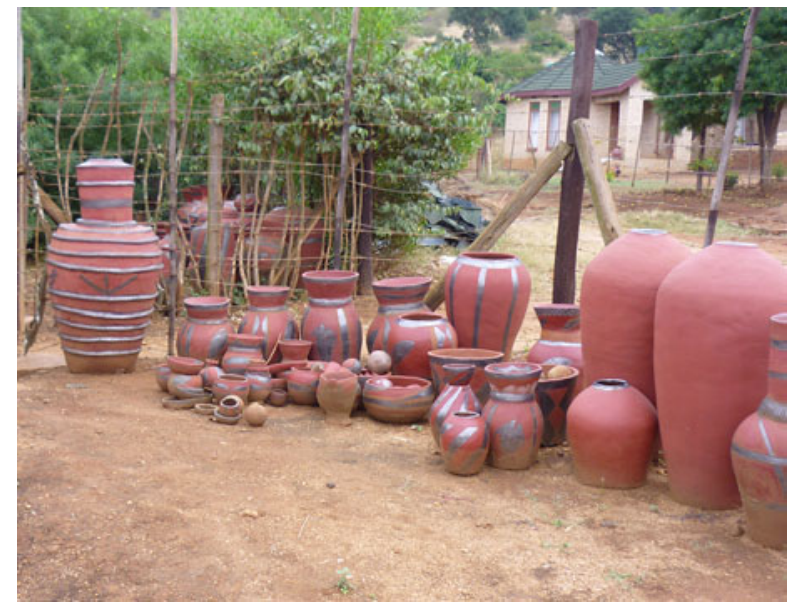

Fig. 4 Some of the modern wares made by potters from Mashamba village, northern South Africa. Photo by A. Lindahl 
In Zimbabwe, our survey covered northern, south-central, and east-central parts of the country (Fig. 1). Here, potters fall under one umbrella identity of Shona, although those in the northern regions identify themselves as Korekore, while those in the south and east-central regions identify as Karanga. Like in northern South Africa, most potters lived in rural areas, some distance away from the nearest urban centers. Unlike in South Africa, they made wares mainly for domestic use, but sometimes exchanged their products within nearby villages or regions for grain or small livestock.

All the potters interviewed were women (Fig. 5). The only role men play in the production of pottery is assistance with the transportation of clay from the quarry to the homestead. The potter usually learned the handicraft from an aunt, not her mother. Among Shona speakers, it is common practice that girls stay in the household of their fathers' sisters. Knowledge of potting is also transmitted in a polygamous context by the more senior wives teaching their skills to the younger wives within the household and adjacent clan. In this context, most of the potters interviewed indicated that, when a new bride came into her husband's household, she would bring a pot from her home to cook the first meal for her father-in-law and mother-in-law and her husband. This pot stayed with her. One of the interviewed potters was originally from Malawi and had brought with her a cooking pot, which was clearly different from pots made locally. The pots she made resembling Malawi cooking pot became popular in the area, such that she was asked to make several pots for the local community. It seems in this context ceramic style was influenced by social networks generated by broader familial alliances, including marriage (see Esterhuysen 2008).

Ceramic production is ritualized. Women observe several taboos specifically for women during the digging of the clay for potting (Lindahl and Pikirayi 2010). A woman is prohibited from quarrying clay if she is in her menses, is pregnant, or has had sexual intercourse just prior to the event. Young boys are not allowed to participate in the digging of the clay as it is believed this would cause the clay to crack during potting. Some potters do not allow sharp metal objects to be brought to the clay quarry, while others bar coins. Furthermore, in order to ensure the success of the manufacturing process, a small offering, such as a lump of clay or bundle of twigs, is sometimes thrown back into the clay source or placed nearby. One potter added very small amounts of ground potsherds to her clay mixture. This cannot be characterized as

Fig. 5 A potter in Guruve, northern Zimbabwe displaying her household range of vessels. Photo by A. Lindahl

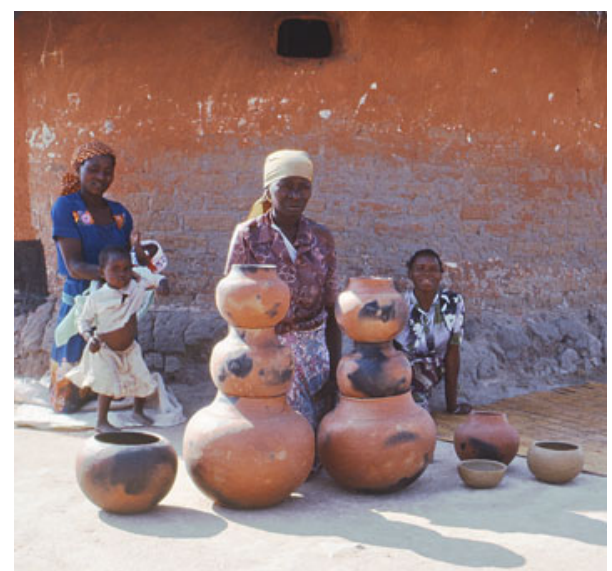


temper, but rather something that symbolizes continuation of certain cultural practices. She regarded it as "a way for the spirit of the old pot to live in the new one." Similar traditions are also known from Sudan (Else Johansen Kleppe, personal communication). The same potter, who also claimed to be a spirit medium, made pots she described as "ceremonial," such as small containers for storing liquids and clay ladles, both items for use during such occasions.

The distribution of the vessels points mostly toward localized, village networks of interaction, but sometimes extended to regional markets. Most of the potters made vessels for their own use and for the local village, the latter almost exclusively made on request. One potter made several large cooking pots that she kept at her homestead and also had several cooking vessels that she loaned to others in her village (Fig. 6). Besides pots associated with food preparation and grain storage, several were made for cooking, brewing, storing, and serving beer. In one case, several potters worked together as a collective. Although most of the pots they produced were of the indigenous cooking and storage/drinking type, they also crafted European types resembling coffee pots, different types of candlesticks, bowls, etc. (Fig. 7). These potters distributed their pots to the wider region.

One aspect of the production process which we thought would inform us about the social aspects of ceramic production was decoration. However, the answers we obtained with regards to its purpose and meaning were not particularly helpful, as most potters told us that it was "to beautify the pot." A few answers pointed to decoration serving a symbolic significance, especially when vessels are used for ceremonial purposes; for example, during weddings, the pots for the bride and the groom may be decorated in a special way (Fig. 8). In some cases, our informants pointed to pots as symbols and representations of the human female body. The subject of decoration requires more in-depth discussion to understand its uses and meaning. The indications are that decoration is communicative, going beyond simple ethnic identities, which as used in Southern African Iron Age studies, has been consistently but narrowly prescribed.

\section{Discussion}

In the ensuing discussion, we revisit the question of the social meaning and significance of archaeological ceramic assemblages found in different site contexts. What is implied by domestic ceramic assemblages of various sizes found within sites? Our paper provides an opportunity to rethink the meaning of ceramic assemblages in archaeological contexts, where we point to the complexities of ethnohistory and ethnography in

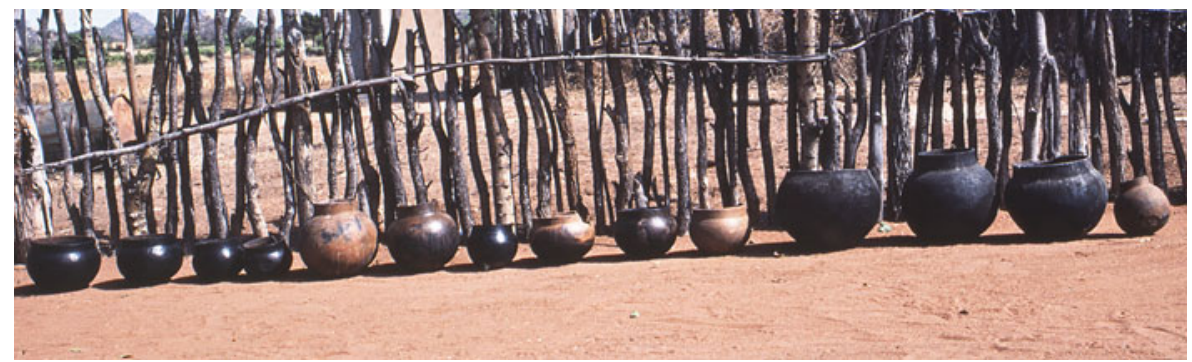

Fig. 6 A household assemblage showing the range of vessels in possession by a potter. Several of these were intended for rent by others in the community. Photo by A. Lindahl 


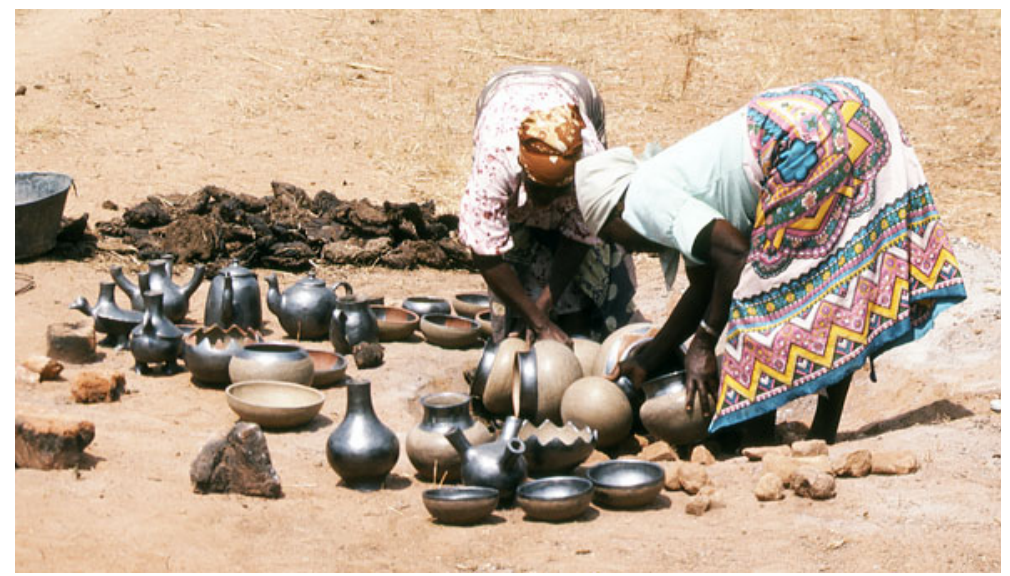

Fig. 7 Imitations of European vessel types such as kettles and candlesticks. Note the elaborate use of graphite to imitate the luster on metal vessels. Photo by A. Lindahl

helping to explain the past. Modern ceramic production, which shows continuities from the past, may also help in locating some of the answers, but we must add some caution as the production process is now conditioned by economic and social considerations which are different from those we seek to define in the context of the past. Some ethnoarchaeological studies in Zimbabwe have sought to understand settlement abandonment, characterized by material culture patterning (Lindahl and Matenga 1995). Our discussion here focuses on the internal dynamics of settlements to appreciate the social role of material culture items such as ceramics, rather than the "leaving" processes, although of course assemblages are also a result of these.

A ceramic assemblage is representative of local and regional interaction of people and communities. This interaction is both diachronic and synchronic, in the sense that there is a communicative process between the living communities and the dead, on one hand, and among the living peoples themselves, on the other hand. The social dimension involving communication with the ancestral world is evident when you examine

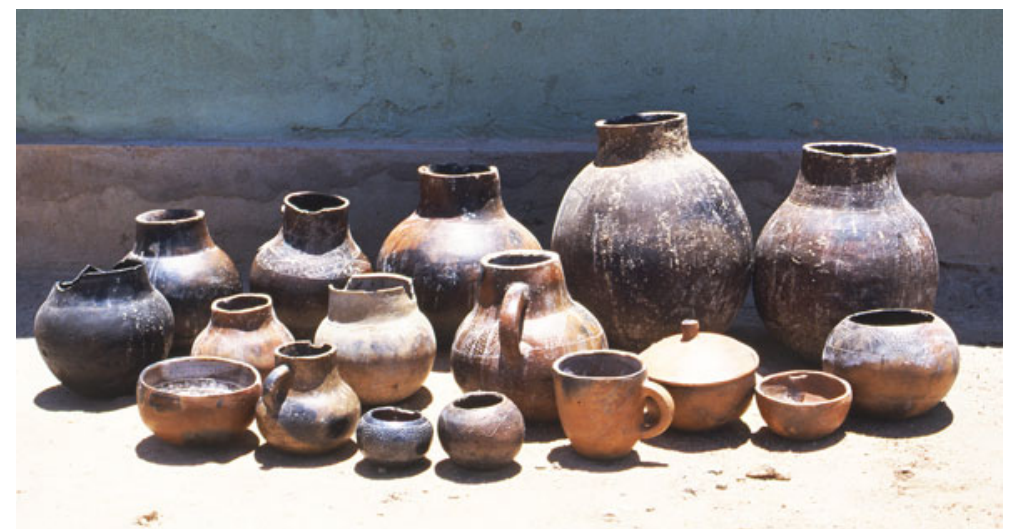

Fig. 8 A ceramic assemblage recorded from a medicine man and rainmaker in Masvingo, south-central Zimbabwe. Photo by A. Lindahl 
pottery in burial contexts, which, for the Musengezi tradition site of Mbagazewa cited here, shows the pottery found in living sites is similar to that (in terms of shape forms, decoration, and range of vessels) as that found in human burial places (Pikirayi 1987). The archaeological interpretation of the assemblages from such sites should, therefore, take spatial context into account, rather than proffer the same ethnographic explanations and ascribe blanket notions of ethnicity, as has been the case with a number of Iron Age studies. In the context of the Musengezi tradition, interpretations of Mbagazewa as belonging to a single lineage suggest the possible forms of social identities that need to be ascribed to such places. In this case, ceramics provide the medium with which such identities are communicated between the living and the departed. That people were repeatedly buried in this rock shelter points toward such contexts reflecting social and familial ranking, as well as the social status of the buried individuals, who are accompanied by material culture including ceramic vessels.

The social networks involved in the movement of ceramic vessels beyond the village suggest trade for vital commodities such as grain, iron tools, and livestock. We know this was definitely the case at the site of Baranda since trade goods have been recovered there. Bent (1969) references villagers in southern Zimbabwe during the late nineteenth century, who monopolized pottery production and traded their wares for grain, cattle, and iron. While quite unusual in that such potters were not subsistence farmers, this is important in highlighting that movement and distribution of vessels across the region involved broader networks of social and commercial interaction.

These broader social networks of interaction may be inferred from the archaeological record by the presence of large ceramic assemblages from within a single related context. The quantity of the sherds as well as their surface finish from the site of Baranda suggests an assemblage serving a function beyond domestic usage, such as for cooking and storage (Table 1; Fig. 9). While a majority of the pottery was evidently used for cooking to serve daily subsistence needs of the site's inhabitants, some was traded in exchange for imported earthenwares, stonewares, porcelains, and other items such as glass beads (Table 2). The identification of graphite-burnished pottery within a $5-\mathrm{km}$ radius of the site of Baranda points to such movement of the ceramic craft. In this

Table 1 Distribution of sherds of local pottery at the site of Baranda, northern Zimbabwe

\begin{tabular}{lrrrr} 
Vessel parts & Surface & Test pits & Trench I/IA & Total \\
\hline Rim sherds & 202 & 179 & 874 & 1,255 \\
Rim necks & 58 & 6 & 3 & 67 \\
Necks & 150 & 117 & 447 & 714 \\
Rim neck shoulder & 0 & 0 & 0 & 0 \\
Rim neck shoulder body & 0 & 0 & 0 & 0 \\
Neck shoulders & 74 & 10 & 44 & 128 \\
Shoulders & 8 & 22 & 42 & 72 \\
Body sherds & 1,947 & 992 & 3,824 & 6,763 \\
Base sherds & 0 & 2 & 5 & 7 \\
Total & 2,439 & 1,328 & 5,239 & 9,006 \\
Frequency (\%) & 19.64 & 27.64 & 45.64 & 100
\end{tabular}



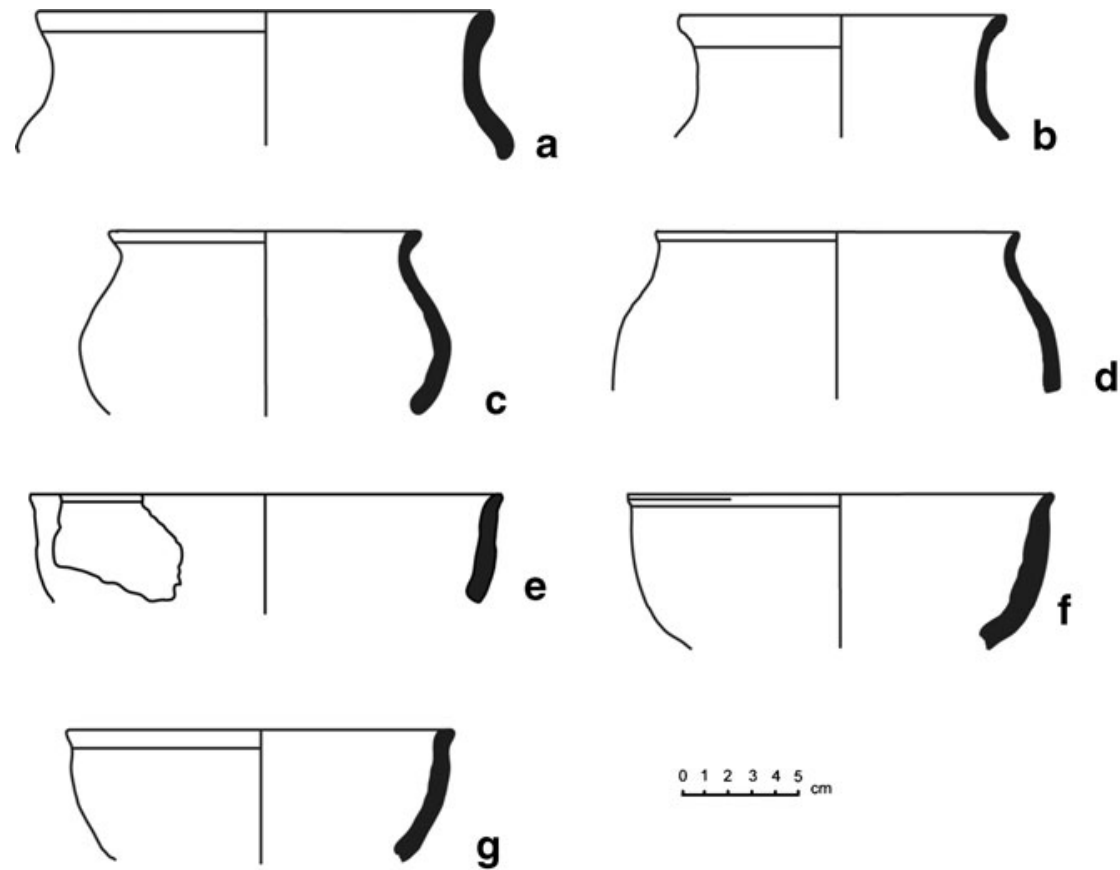

\begin{tabular}{llllll}
0 & 1 & 2 & 3 & 4 & 5 \\
\hline
\end{tabular}

g
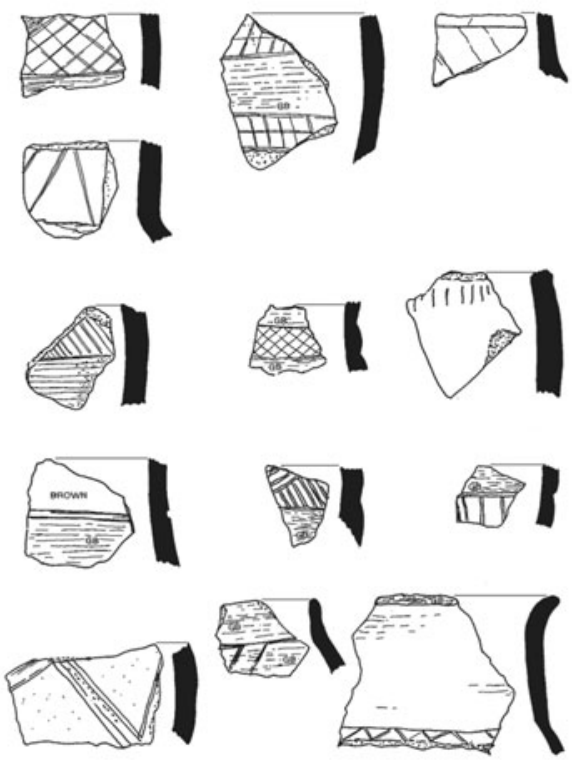

$0 \begin{array}{llllll}0 & 2 & 3 & 4 & 5 & \mathrm{~cm}\end{array}$

Fig. 9 Some of the local earthenwares recovered from the site of Baranda, northern Zimbabwe

context, therefore, the ceramic assemblage at Baranda was a transient one, ready to be moved to other places as determined by market, social, and other demands. Our observations of the pottery manufactured by villagers from Mashamba in northern 
Table 2 Distribution of various types of imported ceramics at the site of Baranda, northern Zimbabwe

\begin{tabular}{lccccr} 
Site context & Stoneware & Earthenware & Porcelain & Glassware & Total \\
\hline Surface collections, random & 50 & 73 & 160 & 14 & 297 \\
Surface collections, controlled & 28 & 29 & 34 & 5 & 96 \\
Test pits & 12 & 10 & 11 & 6 & 39 \\
Trenches I and Ia & 18 & 40 & 46 & 14 & 118 \\
Total & 108 & 152 & 251 & 39 & 550 \\
Frequency (\%) & 19.64 & 27.64 & 45.64 & 7.09 & 100
\end{tabular}

South Africa further supports the interpretation of the ceramic assemblage we offered previously. Displaying extensive ceramic assemblages, mostly stored outside houses, Mashamba pots imply a number of processes or activities: the manufacturing process itself, the distribution of the ceramic craft, the open spaces outside the living quarters which served as storage space, and so on. The storage space, in this case, is an extension of the household, representing the transition between manufacture and distribution of the ceramic products. Thus, contemporary observations suggest that pots are not static items of material culture, but rather artifacts moving within the household and the immediate homestead, and ready to move into the landscape or region (see, e.g., Deal 2005).

Besides ordinary day-to-day functionality, which forms the basis upon which pottery is socialized, archaeologists should be able to read how such material culture objects are ritualized. Ritual and, by extension, ceremony, must be inferred not only from the usage of the ceramics but also by the way they are patterned in a given spatial context. The large vessels found within the site of Zvongombe South may be read as such, as they were clearly designed not primarily for purposes of consumption but also for other specialized functions as suggested by the artifacts found therein. The gold bead found suggests that the vessels may not have been serving public functions. Ritual, in this case, is part of patterned spatial behavior (Fig. 10).

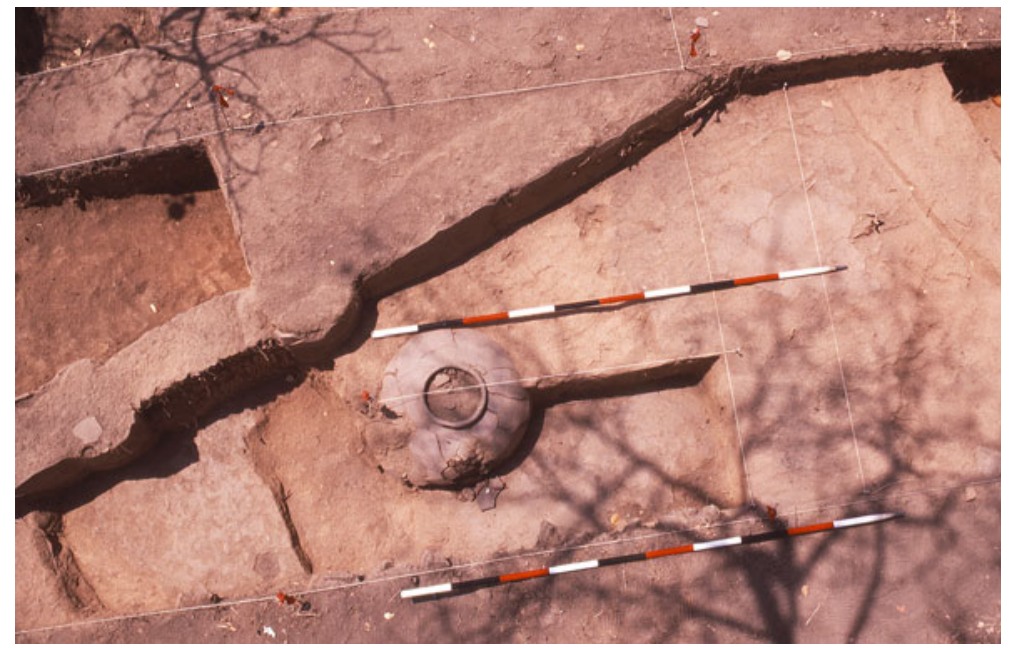

Fig. 10 A large storage vessel recovered from the stonewalled site of Zvongombe, northern Zimbabwe. Photo by A. Lindahl 


\section{Conclusion}

In this paper, we have proposed the need for a closer integration of archaeology, ethnohistory, and ethnography to understand the Iron Age of Southern Africa, and specifically the last five centuries, where some events are covered by written sources. Treating the period in terms of an "ethnographic present" as some scholars have done is in our view inappropriate, since this masks the changes and developments that occurred among various groups over time. We have used ceramics to show that archaeological assemblages change meanings, not just over time but also depending on the context in which they are found and used. The ethnohistoric examples we have cited from some of the written sources as well as ethnoarchaeological studies of contemporary pottery manufacture clearly demonstrate this.

Ceramics are part of a social system, and as such, archaeologists should define and locate the social value of these material culture items in the region's rich archaeological record. This leads toward a better understanding of past social systems and forms of behavior associated with social networks of interaction and exchange. By proposing an approach grounded in ethnohistory, ethnoarchaeology, and other sources to understand the archaeological record, our objective is to illustrate the socially complex meaning and dynamics behind ceramic assemblages. The ethnohistoric record is replete with clues for understanding issues such as function of pottery and meaning within a given cultural landscape. This can also throw some light on group relations and their mobility within social spaces involving marriage alliances and lineage relationships, ritual and ceremony, and trade and exchange. This completes the void left by works that emphasize only the definition of culture sequences and human group identities as inferred by material culture such as pottery.

We conclude here that a pot is a valuable social artifact, part of the broader society in which it was or is located. Its manufacture, usage, distribution, and so on reflect behavioral patterns beyond narrowly conceptualized archaeological ceramic assemblages, which we have primarily but narrowly treated as human ethnic markers.

Acknowledgments This paper is based on fieldwork conducted between 2009 and 2011, where we interviewed 13 potters in both Zimbabwe and South Africa. We have also included data on potters interviewed in the Guruve District of Zimbabwe in 1988. Our fieldwork was funded by the South African National Research Foundation (NRF) and Swedish Research Council (VR) within the framework of the research projects, "Ceramics and the Ethnographic Present: Ceramic Manufacturing Techniques in Southern Africa" (NRF Grant UID 65398 and SA-Swedish VR Links programme), "Ceramics: A Resilient Technology” (South African Biosystematics Imitative Indigenous Knowledge Program, NRF Project Number 75924). The authors sincerely thank potters in both Venda and Zimbabwe for sharing their knowledge and for welcoming us and our postgraduate students to their homes. We also thank peer reviewers for their criticisms and highly constructive comments. We thank François Richard for translating the abstract into French.

\section{References}

Arnold, D. E. (1988). Ceramic theory and cultural process. Cambridge: Cambridge University Press.

Arnold, P. J. (1991). Domestic ceramic production and spatial organization: A Mexican case study in ethnoarchaeology. Cambridge: Cambridge University Press.

Ashley, C. (2010). Towards a socialised archaeology of ceramics in Great Lakes Africa. African Archaeological Review, 27, 135-163.

Beach, D. N. (1980). The Shona and Zimbabwe 900-1850: An outline of Shona history. Gweru: Mambo Press. 
Bent, J. T. (1969). The ruined cities of Mashonaland. Bulawayo: Books of Rhodesia.

Berlyn, P. (1968). Some aspects of the material culture of the Shona people. Native Affairs Departmental Annual (NADA), 9(5), 68-73.

Bourdieu, P. (1977). Outline of a theory of practice. Cambridge: Cambridge University Press.

Calabrese, J. A. (2000). Interregional interaction in Southern Africa: Zhizo and Leopard's Kopje relations in northern South Africa, southwestern Zimbabwe and eastern Botswana, AD 1000 to 1200. African Archaeological Review, 17(4), 183-210.

Calabrese, J. A. (2005). Ethnicity, class and polity: The emergence of social and political complexity in the Shashi-Limpopo valley of southern Africa, AD 900 to 300. Unpublished Ph.D. thesis, University of the Witwatersrand.

Crawford, J. R. (1967). Monk's Kop ossuary. Journal of African History, 8(3), 373-382.

David, N., \& Kramer, C. (2001). Ethnoarchaeology in action. Cambridge: Cambridge University Press.

David, N., Sterner, J., \& Gavua, K. (1988). Why pots are decorated. Current Anthropology, 29, 365-389.

Deal, M. (1988). An ethnoarchaeological approach to the identification of Maya domestic pottery production. In C. Kolb (Ed.), Ceramic ecology revisited, 1987: The technology and socioeconomics of pottery (pp. 111-142). BAR International Series 436, Part II. Oxford: British Archaeological Reports.

Deal, M. (1998). Pottery ethnoarchaeology in the Central Maya highlands. Salt Lake City: University of Utah Press.

Deal, M. (2005). Ethnoarchaeological perspectives on ceramic production and the formation of household ceramic assemblages (pp. 1-20). http://www.ucs.mun.ca/ mdeal/SAA2005/SAA2005web.htm. Accessed 12 June 2011.

Esterhuysen, A. B. (2008). Ceramic alliances; Pottery and the history of Kekana Ndebele in the Old Transvaal. In N. Swanepoel, A. B. Esterhuysen, \& P. Bonner (Eds.), Five hundred years rediscovered: Southern African precedents and prospects. Johannesburg: Wits University Press.

Fisher, W. (1984). Narratives as human communication paradigm: The case for public moral argument. Communication Monographs, 51, 1-22.

Fowler, K. D. (2008). Zulu pottery production in the Lower Thukela Basin, KwaZulu-Natal, South Africa. Southern African Humanities, 20, 477-511.

Fredriksen, P. D. (2007). Approaching intimacy: Interpretations of changes in Moloko household space. South African Archaeological Bulletin, 62(186), 126-139.

Gelbert, A. (2001). Ethnoarchaeological study of ceramic borrowings: A new methodological approach applied in the middle and upper valleys of the Senegal River. In S. Beyries \& P. Pétrequin (Eds.), Ethno-archaeology and its transfers (pp. 81-94). BAR International Series 983. Oxford: Archaeopress.

Gosselain, O. P. (2001). Globalizing local pottery studies. In S. Beyries \& P. Pétrequin, (Eds.), Ethnoarchaeology and its transfers (pp. 95-112). BAR International Series 983. Oxford: Archaeopress.

Gosselain, O. P. (2011). Pourquoi le décorer? Quelques observations sur le décor céramique en Afrique. Azania: Archaeological Research in Africa, 46(1), 3-19.

Guèye, N. S. (2011). Dis-moi quel pot tu as et je te dirai qui tu es! Matérialiser les identités sociales dans les décors céramiques de la moyenne vallée du fleuve Sénégal (nord du Sénégal). Azania: Archaeological Research in Africa, 46(1), 20-35.

Hall, M. (1983). Tribes, tradition and numbers: The American model in Southern African Iron Age ceramic studies. South African Archaeological Bulletin, 38, 51-57.

Haour, A., \& Manning, K. (2011). Identity, fashion and exchange: Pottery in West Africa. Azania: Archaeological Research in Africa, 46(1), 1-2.

Haour, A., Manning, K., Arazi, N., Gosselain, O. P., Guèye, S., Keita, D., Livingstone Smith, A., MacDonald, K. C., Mayor, A., McIntosh, S. \& Vernet, R. (Eds.) (2010). African pottery roulettes past and present: Techniques, identification and distribution. Oxford: Oxbow Books.

Huffman, T. N. (1980). Ceramics, classification and Iron Age entities. African Studies, 29(2), 123-174.

Huffman, T. N. (1989). Ceramics, settlements and Late Iron Age migrations. African Archaeological Review, 7, 155-182.

Huffman, T. N. (2002). Regionality in the Iron Age: The case of the Sotho-Tswana. Southern African Humanities, 14, 1-22.

Huffman, T. N. (2007). Handbook to the Iron Age: The archaeology of pre-colonial farming societies in Southern Africa. Scottsville: University of KwaZulu-Natal Press.

Huffman, T. N. \& Herbert, R. (1994/1995). New perspectives on Eastern Bantu. Azania, 29/30, 27-36.

Huffman, T. N. (1996). Snakes and crocodiles: Power and symbolism in ancient Zimbabwe. Johannesburg: Witwatersrand University Press.

Lane, P. (1994/1995). The use and abuse of ethnography in the study of the Southern African Iron Age. Azania, 29/30, 50-64.

Lawton, A. (1967). Bantu pottery of Southern Africa. Annals of the South African Museum Vol. 49, Cape Town. 
Lindahl, A. (1995). Studies of African pottery for understanding of prehistoric craft. In P. Vincenzini \& S. Faenza (Eds.), The ceramics cultural heritage (pp. 49-60). Proceedings of the International Symposium "The Ceramics Heritage of the 8th CIMTEC," World Ceramics Congress and Forum on New Materials, Florence, Italy, 28 June-2 July 1994.

Lindahl, A. (2000). The idea of a pot: Perception of pottery. In D. Olausson \& H. Vandkilde (Eds.), Form, function \& context (pp. 163-172). Lund: Acta Archaeologica Lundensia, Series in $8^{\circ}(31)$.

Lindahl, A. (2003). Exploring smaller settlements of the Great Zimbabwe Tradition, Buhera Region, Zimbabwe. Proceedings of the Symposium "Urban Landscape Dynamics and Resource Use: An international symposium on multi-disciplinary cooperation," Uppsala, 28-30 August 2003.

Lindahl, A. \& Matenga, E. (1995). Present and past: Ceramics and homesteads. An ethnoarchaeological investigation in the Buhera district, Zimbabwe. Studies in African Archaeology 11. Uppsala: Department of Archaeology, Uppsala University.

Lindahl, A., \& Pikirayi, I. (2010). Ceramics and change: An overview of pottery production techniques in northern South Africa and eastern Zimbabwe during the first and second millennium AD. Archaeological and Anthropological Sciences, 2, 133-149.

Lindahl, A., Chakanyuka, C., Hjärthner-Holdar, E., Löfgren, A., Matenga, E., Stilborg, O., \& Wuta, M. (2000). Ceramics, metalcraft and settlement in south-eastern Zimbabwe since ca. 1400 AD. KFLRAPPORT 00/0406. Lund: Laboratory for Ceramic Research, Department of Quaternary Geology.

Lyons, D. (2009). How I built my house: Gendered technical practice in Tigray, Ethiopia. Ethnoarchaeology, $1(2), 115-136$.

Manning, K. (2011). Potter communities and technological tradition in the Lower Tilemsi Valley, Mali. Azania: Archaeological Research in Africa, 46(1), 70-87.

Marufu, A. (2008). A comparative study of the material culture from settlement and mortuary contexts in northern Zimbabwe-The case of Musengezi tradition. Unpublished MA dissertation, University of Dar es Salaam.

Pikirayi, I. (1987). Musengezi: A description and characterization of a later Iron Age sub-tradition of northern Zimbabwe. Unpublished MA dissertation, University of Zimbabwe.

Pikirayi, I. (1993). The archaeological identity of the Mutapa state: Towards an historical archaeology of northern Zimbabwe. Studies in African Archaeology 6. Uppsala: Societas Archaeologica Upsaliensis.

Pikirayi, I. (2007). Ceramics and group identities: Towards a social archaeology in Southern African Iron Age ceramic studies. Journal of Social Archaeology, 7(3), 286-301.

Pikirayi, I. (2009). Palaces, feiras and prazos: An historical archaeological perspective of African Portuguese contacts in northern Zimbabwe. African Archaeological Review, 26(3), 163-185.

Pwiti, G. (1996). Continuity and change: An archaeological study of farming communities in northern Zimbabwe AD500-1700. Studies in African Archaeology 13. Uppsala: Department of Archaeology, Uppsala University.

Pwiti, G., \& Mahachi, G. (1991). Shona ethnography and the interpretation of Iron Age burials: The significance of burial location. Zimbabwea, 1, 57-59.

Rice, P. M. (1987). Pottery analysis: A sourcebook. Chicago: University of Chicago Press.

Rye, O. S., \& Evans, C. (1976). Traditional pottery techniques of Pakistan: Field and laboratory studies. Smithsonian Contributions to Anthropology 21. Washington, DC: Smithsonian Institution.

Schofield, J. F. (1943). A preliminary study of the pottery of the Bantu tribes of the Union of South Africa. South African Journal of Science, 39, 256-281.

Schofield, J. F. (1948). Primitive pottery. Cape Town: South African Archaeological Society.

Shepard, A. O. (1980). Ceramics for the archaeologist. Publication 609. Washington, DC: Carnegie Institution of Washington.

Stahl, A. B. (1993). Concepts of time and approaches to analogical reasoning in historical perspective. American Antiquity, 58(2), 235-260.

Stahl, A. B., Cruz, M. D., \& Neff, H. (2008). Ceramic production, consumption and exchange in the Banda area, Ghana: Insights from compositional analyses. Journal of Anthropological Archaeology, 27(3), 363-381.

Stayt, H. A. (1931). The Ba Venda. London: Oxford University Press.

Stead, W. H. (1947). Notes on the types of clay pots found in the Inyanga District, 1945, identified from specimens collected for the purpose by native messengers at office of Native Commissioner, Inyanga. Native Association Departmental Annual (NADA), 24, 100-102.

Taylor, G. A. (1927). A Mashona hut. Native Association Departmental Annual (NADA), 5(27), 22-26.

Theal, G.M. (1898-1903). Records of South Eastern Africa (9 vols.). Cape Town: Government of the Cape Colony.

Van Warmelo, N. J. (1944). Multi-mouthed pots from the northern-Transvaal. Native Association Departmental Annual (NADA), 21, 45-47.

Vansina, J. (1995). Historians, are archaeologists your siblings? History in Africa, 22, 369-408.

Wylie, A. (1985). The reaction against analogy. Advances in Archaeological Method and Theory, 8, 63-111. 